\title{
Urban translation and the 2020 Tokyo Games
}

\author{
Patrick Heinrich
}

\section{Introduction}

When Tokyo hosted the Summer Olympics in 1964, the event was seen as a welcome opportunity to present a new and peaceful Japan. The 1964 Olympics paved the way for Japan's postwar economic development and its renewed global integration. The expectations for the 'return' of the Olympics and Paralympics in 2020 (henceforth, the 'Tokyo Games', 'Tokyo 2020 ' or '2020 Games') have been equally high. For the 2020 Games - planned to be held in 2021 due to the worldwide Coronavirus pandemic of 2020 - the intention is to show the world that 'Japan is back' after decades of economic stagnation and the triple disaster of Fukushima in 2011. The Games are also seen as an occasion to present Tokyo as a cosmopolitan city and Japan as a multicultural society (Robson 2016: 55). In short, Tokyo 2020 presents an opportunity to project a new image of the city (and Japan) to a global public. The Tokyo Games are also seen as an opportunity to transform Tokyo, and to use the case of Japan's capital as a blueprint for changes across Japan (Ichikawa 2015). This desire already manifests in the slogan that accompanied Tokyo's Olympic bid, which stated that 'it is now that Japan needs the power of this dream' (ima, nippon ni wa kono yume no chikara ga hitsuyō da) (TOCOPG 2012).

Two questions come immediately to mind when reflecting on the 2020 Games. What does Japan want to achieve by hosting the Games? In addition, will the 2020 Games be a similar success in their transformational potential as the 1964 Games were? The response to the first question is partly formulated in the campaigns that rationalized Tokyo's bid to host the Games. These answers are also prominently reproduced in the preparation for the megaevent. Three core concepts characterize its official vision: 'Achieving personal best', 'unity in diversity' and 'connecting to tomorrow' (TOCOPG 2019). In the language of the International Olympic Committee and the Tokyo Organizing Committee, the 2020 Games are also meant to produce a legacy. This legacy is to be at the same time of a sportive, spiritual, cultural, social, environmental and economic nature. At least at the level of official rhetoric, expectations for the Tokyo Games are sky-high.

The aim to create a social legacy merits particular attention for the topic of urban translation. The Bureau of Olympic and Paralympic Games Tokyo 2020 Preparation intends to 'create an intercultural society where foreign residents can participate and be successful to 
realizing a Tokyo where everybody can live a lively and rich life', and it seeks to 'create a supportive, inclusive society for all people based on mutual respect' (BOPGTP 2016: 28). This chapter examines linguistic aspects of this objective, in particular issues of language policy and planning and its manifestation in the linguistic landscape of Tokyo.

Language crucially contributes to the specific feel of a city. Every urban conglomerate feels city-like and simultaneously has something specific that sets it apart from other cities. For our case here, there is a sense of Tokyoness, or Tokyorashisa in Japanese, that can be experienced and that is permanently recreated (Heinrich 2019). This linguistically constituted Tokyoness is not to be confused with the vision of Tokyo that underlies the language planning for the 2020 Games. This discrepancy between what I call here the language ecology of Tokyo and the envisioned and implemented linguistic order in the linguistic landscape is bridged by a process of urban translation. Translation in this chapter draws loosely on translation sociology, where the emphasis is placed on the envisioned outcomes of translation processes (Collon 1986). In more concrete terms, urban translation is caused by a felt necessity to 'conduct the conduct' of a dense, diverse and mobile urban population. Although the idea of urban translation is solely created for the sake of discussing the case of the 2020 Games in this chapter, I would like to offer the following working definition and research agenda:

- Urban translation refers to activities of orchestrating conduct in public space that is necessitated by the diversity and mobility of urban dwellers with the aim to mediate potential conflicts that may arise as an effect of this diversity and mobility.

- Research into urban translation addresses the specific choices and outcomes of orchestrating conduct in public space, the assumptions that guide them, as well as the tensions and contradictions that exist between the objectives, outcomes and the underlying assumptions of urban translation.

Discussing the envisioned effects of urban translation in Tokyo requires some basic knowledge about Tokyo such as its demographic and linguistic composition. I will therefore first present a brief portrayal of the city, before turning to language planning for the 2020 Games. In the last part, I will discuss the contradictions that emerge between ecology and planning and its implications for Tokyo's diverse public as a process of urban translation.

\section{Tokyo's language ecology}

Although defined as a global city along the likes of New York and London by scholars of urban studies already three decades ago (Sassen 1991), Tokyo remains to be seen as an atypical global city to this very day. The main reasons are its comparatively small share of migrants and the fact that the city shows relatively little traces of cosmopolitan culture (White 2011). As we noted earlier, the Olympics represent a welcome occasion to correct this image. It is a stated objective to project a picture of Tokyo as cosmopolitan and multicultural to the outside world. This objective is entirely new for Japan, as it had preferred to present itself as a monocultural society ever since the loss of its colonies in 1945 (Oguma 2002). However, the self-invented myth of Japan as a monolingual and monocultural nation has been silently crumbling for decades, and its correction is long overdue. For one, the diversification of Japanese society has been continuously advancing (Nakane et al. 2015), and also Japanese ethnolinguistic minorities have become more vocal and therefore more visible and difficult to explain away (Heinrich 2012; Heinrich and Galan 2011). 
Tokyo has seen dramatic changes since it last hosted the Summer Games in 1964. The population of Greater Tokyo stood at 20 million in 1964, and it is 37 million today. Half of its population was 25 years or younger in 1964, but this median age is now 47 years. Japan's capital city hosts a much older society and, as a matter of fact, its population is since 2020 in decline as an effect of these demographic changes. There were fewer than 10,000 foreign residents in Tokyo in 1964, versus half a million today. Tokyo received 12 million tourist visits in 2019, and an additional one million are predicted to come specifically for the Games. Tokyo was not a popular tourist destination in 1964, and there is no data available on the number of tourists in the city then. Today, 40 million people arrive with international flights at Haneda and Narita Airport every year. Tokyo is also home to an ever-growing number of Japanese who have worked, studied or lived abroad, and to international couples and their bilingual children. The stereotype of a linguistically and culturally homogenous Japanese society is hard to uphold for contemporary Tokyo (Heinrich and Yamashita 2018). Tokyo's ongoing internationalization also manifests in the fact that 51 Fortune 500 companies have offices in the city today, and that more than $75 \%$ of the foreign-affiliated companies in Japan are located there. Also, Japanese global companies such as Sony, Hitachi, Canon, NTT DoCoMo, Rakuten or Casio have their headquarters in Tokyo, making Greater Tokyo the largest urban economy of the world (Tokyo Bureau of Industrial and Labor Affairs 2017).

Tokyo's growth into the world's largest urban conglomerate and its many multinational ties also leaves linguistic traces. Heide Imai (2018: 1) starts her book on Tokyo with the following words: 'If the streets of Tokyo could talk, we would hear of crowds and emptiness; tradition and modernity; old and new; mess and order; and unexpected and familiar encounters that change with every street corner one turns onto'. One would also hear many different languages - the languages of tens of thousands of Ryukyuans and more than 5,000 Ainus who migrated from the extreme south and north of the Japanese Archipelago to Tokyo (Aniya 1989; Watson 2014) and also the languages of Koreans and Chinese nationals who arrived in Tokyo already at the end of the 19th century (Maher and Yashiro 1995). The number of foreign residents that have arrived since the 1990s when immigration laws were changed in Japan has been steadily growing (Otomo 2019). In 1990, 220,000 foreign nationals were registered in Tokyo, but this number grew in the past five years alone from 394,000 in 2014 to 567,789 (Ministry of Justice 2019). The foreign population that moved to Tokyo since the 1990s are called newcomers in Japan. These migrants differ from the so-called oldcomers in that they are more diversified and no longer silently assimilate. Tokyo's linguistic diversity is visible and audible today (Otsuji 2019). While Korean residents once amounted to a whopping two-thirds of the entire foreign population in Tokyo, this rate stands today at less than $20 \%$. Chinese nationals are today the largest foreign community in Tokyo, followed by Koreans, Vietnamese, Filipinos, Nepalese, Taiwanese, Indians, and Myanmar and Thailand nationals (Tokyo Metropolitan Government 2018). The presence of Asian migrants and residents and their languages crucially contribute to the feel of Tokyoness in the city. It is also noted in this context that the aforementioned countries are in themselves linguistically diverse. If we add up the number of languages spoken in these nine countries, one arrives at more than 1,000 languages (Eberhard et al. 2019). If adding the 12 million tourists who visit Tokyo every year (at the moment of writing this chapter) to these foreign residents, one can safely estimate that several hundred different languages may be present at any time in contemporary Tokyo, the vast majority of them being Asian languages.

Tokyo's and Japan's ongoing and increasingly manifest linguistic diversity notwithstanding, Japan's language and language-in-education policy continues to be rooted in the debunked 
monolingual myth of Japanese society. It continues to reproduce a Japanese-foreigner binary and does little to pave the way towards intercultural exchange, engagement and negotiation (Liddicoat 2013). English language skills remain a problem despite much effort to improve them (Seargeant 2009), and language attitudes remain often essentialist and purist (Cultural Agency 2018). Added to this are the unhinged anti-Korean 'hate speech' demonstrations on the streets of Tokyo's Koreatown in Shin-Ōkubo in the early and mid-2010s (Itagaki 2015) and the extremely negative perception of Chinese and Korean nationals by Japanese society today - only 26\% express to 'feel sympathy' (shitashimi o kanjiru) for Korean nationals and $22 \%$ for Chinese nationals (Shakai Jijō Dēta Zuroku 2019) — and one cannot but arrive at the conclusion that Japan's transformation into a multilingual and multicultural society is not advancing as smoothly as Olympic rhetoric envisions. It is fraught with contradictions and conflicts (Yasuda 2011), and present-day Tokyo finds itself in the middle of this transformation. Tokyo is linguistically diversifying but at the same time also a site of purist, essentialist and at times even discriminatory attitudes and policies. This is why we find seemingly contradictory accounts about Tokyo. Heinrich and Yamashita (2018: 139), for instance, write that 'Japanese minorities, overseas migrants, bilingual families, a growing number of Japanese speaking foreign languages, cosmopolitan and transnational residents are characteristic features of the city', while Mansfield (2016: 191) portrays Tokyo as a 'city that has denied its diversity'. Both views are not necessarily incommensurable, but an expression of ongoing change.

Whatever position one takes, we run into a methodological problem of how to grasp or describe Tokyo's transformation, because the city, or its sense of Tokyoness, is being reproduced and thereby altered every day anew. It is helpful in this context to recall how everyday life in the city evolves from a theoretical perspective. Michel de Certeau writes the following on how daily life in the city is shaped and experienced:

The ordinary practitioners of the city live "down below", below the thresholds at which visibility begins. They walk - an elementary form of this experience of the city; they are walkers. Wandersmänner, whose bodies follow the thicks and thins of an urban "text" they write without being able to read it. These practitioners make use of spaces that cannot be seen. . . The networks of these moving, intersecting writings compose a manifold story that has neither author nor spectator, shaped out of the fragments of trajectories and alterations of spaces: in relation to representations, it remains daily and indefinitely other.

(de Certeau 1984: 93)

To recapitulate this quote in my own words, the numerous movements and interactions of individuals shape the city, e.g., create a sense of Tokyoness in our case. Individuals simultaneously create and experience the city. This means that the city does not exist 'by itself' or 'as such', but it exists only in this mode of permanent (re)production. This mode of reproduction is in turn responsible for the fact that any city is at any time both new and familiar. Any sense of novelty also involves a constant process of becoming familiar with it. This process prompts Christine Deprez (2018: 161) to write (about Paris) that 'in a cosmopolitan city you feel like a stranger even if you are native to the city'. The metropolis is lived and experienced every day anew, and its inhabitants need to be prepared, already out of necessity, to encounter new and unexpected experiences at any moment of time.

If we apply these insights to the case of Tokyo, we come to understand that the novelty of Tokyo is not simply constituted by the presence of visitors or tourists, or by hosting the megaevent of the 2020 Games. Tokyo is, after all, a city that grew from one million inhabitants in 
the 1870 s to 37 million today. This means that it has always been incorporating 'strangers', and that this crucially contributes to the sense of Tokyoness one experiences (and creates) there. Cities are places where strangers meet. Put differently, visitors and tourists simply add further diversity and unexpectedness to that which is already in place.

It is now abundantly clear that language planning and the new creation of public signs for the 2020 Games can only be a gross simplification of the creation and experience of everyday life. Tokyo's language life is not simply hybrid and fluid, as that of any late-modern society. It also involves a high number of different languages through which the city is lived and experienced. These languages involve Chinese, Korean, Vietnamese, Nepalese and other immigrant languages, Japanese Sign Language, all dialects and indigenous languages of Japan, but there are also the experiences of and encounters by blind or illiterate residents (for an ethnographic account, see e.g., Nakashima 2016). The city is thus linguistically (re)created, experienced and altered day by day in multiple ways, and therefore the city can never be fully described or have its linguistic diversity mapped somehow. Cities are forever unfinished projects, and it goes without saying that this holds also true for Tokyo, the largest city on earth.

\section{Planning for the 2020 Tokyo Olympics}

Language planning for the 2020 Games is ambitious. It aims to create a public sphere that is accessible to all, regardless of their linguistic background or possible linguistic and sensory disabilities. It aims to be kotoba no baria furī (linguistically free of barriers). The Games are also envisaged to provide a blueprint of how 'to create an inclusive society where every member of society lives with respect for the rights of others, regardless of age, disability, nationality, or cultural difference, and works together' (Tokyo Metropolitan Government 2016). The absence of linguistic barriers was also identified as one aspect where the Tokyo Olympics are expected to leave a legacy, e.g., have societal effects that remain beyond the Games themselves (TOPJK 2016). Discussions of how to create a public space free of linguistic barriers gravitated around the key terms tagengo taiō (multilingual support) and tagengo taiōryoku (abilities for multilingual support) (Ozawa 2019). Both terms do not translate easily into English - they literally mean 'multilingual + response' and 'multilingual + response + strength', respectively.

The consideration of how to linguistically construct and translate the urban space for the 2020 Games was fuelled by a lingering concern that the world might perceive Japan as not sufficiently international, cosmopolitan and global (see, Atkinson 2015). This is the larger background into which all planning activities for the Tokyo Games were embedded. While Japan has by now a complex and ever-expanding policy that regulates immigration, a rough outline of a migrant society in Japan was only published in 2018, and Japan's once-celebrated self-image of a homogenous nation needed to be replaced by a new multicultural Japan theme in the process (Otomo 2019). In its 'Comprehensive measures for acceptance and integration of foreign human resources', the Japanese government proposes a range of objectives, identifies a number of institutions concerned (school, employment, life services, etc.) and ponders on the means of how to 'realize a society of harmonious coexistence' with foreign nationals (Ministry of Justice 2018: 2). It does so by acknowledging that the number of foreign visitors and residents is at a record high, and that this number needs to further grow to address Japan's demographic problems (social aging and population decline) and to develop its burgeoning tourist industry. Urban planning in Tokyo for the 2020 Games is meant to be fully in line with these national objectives.

In order to prepare for barrier-free communication during the Olympics, the Council for Multilingual Support (Tagengo taiō kyōgikai) was set up in March 2014. It was composed of 
civilians and bureaucrats but involved no language experts or foreign residents. It was tasked to develop guidelines for traffic infrastructure and to assist in improving multilingual information at tourist spots and for tourist services. The Council published its 'Basic concepts for multilingual support' (Tagengo taiō no kihonteki na kangaekata) in 2014, and on the basis of this document a number of websites were subsequently created to assist the compilation of multilingual information, e.g., for restaurant menus (see, Tokyo Metropolitan Government n.d.). These basic concepts proposed by the Council were also to inform the language planning efforts for the 2020 Games. In concrete terms, the aim was that of 'improving the urban environment in a way that foreign tourists could move around smoothly and have a safe and comfortable sojourn' (TOPJK 2016: 19). We note in this context that the 'Basic concepts for multilingual support' addresses only the communicative needs of foreign tourists and entirely ignores the presence of foreign residents in Japan.

Tourists in Japan do experience linguistic difficulties, but a survey among foreign visitors revealed that they were more troubled by the absence of free public Wi-Fi and that communication problems ranked only second, followed by difficulties in obtaining information on public transport. The lack of foreign language information in the linguistic landscape was also identified as a problem (for a discussion of such surveys, see Kitajima 2015).

In a surprising move, the Council for Multilingual Support set the default model for public information on public signs (official or in vitro linguistic landscape) for the 2020 Games to have 'its basis in Japanese, English and pictograms' while 'Chinese, Korean or other languages could be included only in case that demand, regional characteristics, visibility, etc. required it' (TOPJK 2016: 19). This marks a radical departure from the regulations that had been put in place on the occasion of the 2002 FIFA World Cup. In order to prepare for the 2002 megaevent, the official linguistic landscape had involved Japanese, English, Korean and Mandarin-Chinese (Backhaus 2007: 81-82). This new policy of using mainly Japanese and English only has been harshly criticized, and it has been interpreted as a sign of regression in Japan's efforts to adapt to its diversifying society. There is an uncomfortable impression that this new policy is somehow related to the worsening relations between Japan, Korea and the People's Republic of China in the past decade, and that it reflects the negative views the majority of Japanese nationals hold about the two countries and their people. It can also be interpreted in the way that the Olympics are used as an occasion to affirm Japan's place in the world by downplaying the presence and prominence of anything Korean or Chinese in the city. In any case, it has also explicitly been pointed out that the newly imposed linguistic landscape appears to contradict the official omotenashi (Japanese hospitality) philosophy in no uncertain ways (see, e.g., Inoue 2015: 5). Ozawa (2019: 36-37) criticizes that this new default model seems to assume that multilingual means simply 'adding English'. He further adds that rather than informing the public in the best possible way, the new linguistic guidelines for the Olympics seem to be mainly combating the international stereotype that Japanese do not speak English. The new policy of using primarily Japanese and English was defended by the Council for Multilingual Support by a survey that showed most Olympic Games host cities since 2000 had implemented a similar policy of using the national language and English only. It was therefore decided that Tokyo 2020 should also follow this basic 'national language + English' template for disseminating information in the public space (Kitajima 2015: 159).

In more detail, the guidelines of the Council for Multilingual Support stipulated that written public information in public space should give more salience to Japanese than to English. Information in Japanese should ideally occupy two-thirds of the space and English the remaining one-third. These basic concepts of regulating language choices (Japanese, English, pictograms) and the salience of languages in the linguistic landscape are fully in line with the 
'Guidelines for improving and strengthening multilingual support for the realization of a tourism nation' that was published by the Ministry of Land, Infrastructure, Transport and Tourism (2014) in the same year. This guideline was also accompanied by a translation wordlist and a list of pictograms with explanations of how to use them. The wordlist translates Japanese expressions into English, Chinese (simplified characters) and Korean, and it addresses three broader types of multilingual communication: (1) information related to prohibition and calling for attention, (2) information related to guidance and location, and (3) information that promotes the understanding of specific exhibits. A number of further hands-on information on how to improve international communication, and the regulations underlying the creation of multilingual services, can conveniently be accessed on a site of the Bureau of Olympic and Paralympic Games Tokyo 2020 Preparation dedicated to multilingual support (BOPGTP 2014-2020). The outline of the basic concepts on how to assure barrier-free communication ends by stating the following objective (TOPJK 2016: 26):

If it becomes possible to exchange information with people with disabilities, understand each other in public spaces where communication takes places (sightseeing, transportation, resident contact, hospitals, shopping, etc.) ..., to promote mutual understanding, to realize a diverse society and to deeply understand Japanese culture and foreign cultures, their histories and way of thought, then we can enter a new phase where we can understand the world and the world can understand Japan.

(TOPJK 2016: 26)

This long-winded statement includes basically all prominent soundbites that accompany Japan's discussion of a transformation into a multicultural society, e.g., sōgō rikai no sokushin (promoting mutual understanding) or tayōsei shakai no jitsugen (realizing a diverse society). However, despite the use of these well-intended catchphrases, this statement also makes clear that the underlying notion is the familiar binary according to which Japan is homogenous (not diverse), that there is no knowledge of Japan outside Japan and little understanding between Japan and the rest of the world. Essentialist and binary assumptions about Japanese and the rest of the world remain in place. The 'Japan versus the unified global rest of the world' assumption that informs the language planning for the 2020 Games rests on the belief that Japan is not diverse and, what is more, takes no interest in seeing the rest of the world is not a monolithic unity either. There is no acknowledgement of diversity within Japan or outside of Japan. Furthermore, contact between Japan and the rest of the world is never imaged or to ever involve any change or activity beyond 'deeply understanding' (fukaku rikai suru) set and seemingly unalterable differences. We find no signs of mutual engagement beyond that of respecting, understanding and maintaining differences, which serve to constitute Japan as monolithic. We will turn to the implications this has for the diverse individuals that make up Tokyo's public space in the discussion of urban translation in the last part of this chapter.

Let us consider some examples of how these guidelines manifest in the concrete linguistic landscape in the vicinity of the newly built Olympic Stadium in Tokyo. The following examples were collected in February 2020 by the author. The main Japan Railway station near the Olympic Stadium is that of Shinanomachi on the Chūō-Sōbu Line. Above its central exit, we find the following sign which gives indications in Japanese and English (Figure 8.1).

As could be expected, this sign follows the new stipulations for public signs. The relation in size between Japanese and English stands at 3:1. Since the sign refers to specific buildings and facilities, no pictograms are used here. Contrary to the linguistic landscape of Tokyo, neither Korean nor Chinese is used, and we can also note that Meiji Jingū has not been translated 


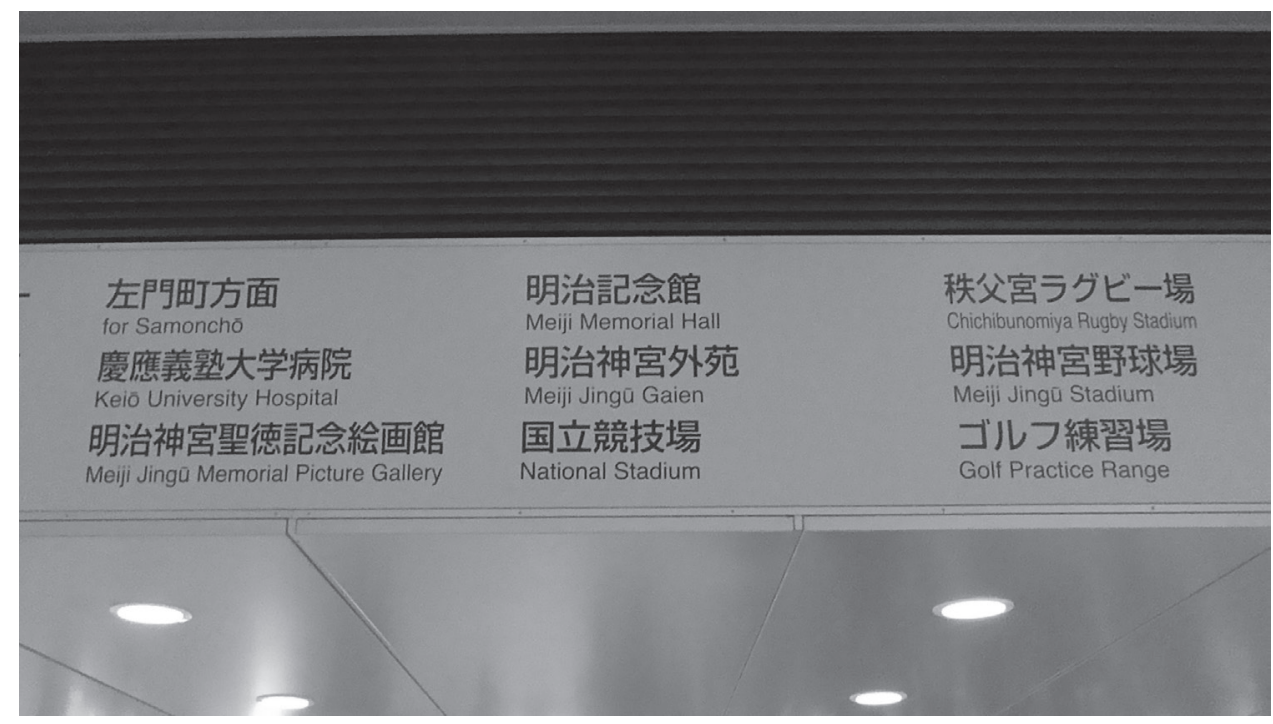

Figure 8.1 The sign above the exit of JR Shinanomachi Station

as 'Meiji Shrine' but simply transcribed in Latin alphabets, making the meaning opaque for whoever does not speak Japanese.

Highly multilingual signs can be found on pedestrian traffic lights around the stadium, where the indication to press the button is given in four languages (Japanese, English, Chinese and Korean). The relation is again 3:1 in favour of Japanese. In addition, a QR code at the traffic light gives access to information in 11 further languages (Chinese, French, German, Spanish, Italian, Portuguese, Russian, Thai, Vietnamese, Indonesian and Arabic), either by writing on the phone display or by voice emission (Figure 8.2).

The intention of this sign is probably to provide barrier-free infrastructure in various languages for people with impaired vision. The audible signal is meant to help them better understand when it is safe to cross the street. Its utility for people with impaired vision remains doubtful, however. Those who have to rely on the languages that can only be accessed by QR code will in all likelihood find the fonts too small to read. It is also not clear why the font size of the four main languages has to differ, since the degree of impairment is not contingent on the language somebody speaks. It seems as if this traffic light and its multilingual appliance is symbolic rather than practical. It is simply a display of good will or a manifestation of the technological feasibilities that exist in Japan today.

A third example shows the salience of pictograms in Tokyo's freshly revamped linguistic landscape. Located opposite to the Olympic Stadium, at the entrance of the Japan Olympic Museum, the following signs remind visitors of various restrictions in this public space (Figure 8.3). In signalling prohibitions, the well-established conventions of round signs, red colour and a crossing bar serve as an easy-to-comprehend framing of the message.

These signs are also a prototypical example of how the new linguistic landscape in Tokyo ought to look henceforth. It is English/Japanese with more salience given to Japanese, and it is prominently accompanied by a pictogram that follows international conventions (e.g., round, red, crossed-out signalling prohibition). That said, it is unlikely that 'not playing music loudly' is successfully conveyed in one of the pictograms, and the same applies to the "no sales and 


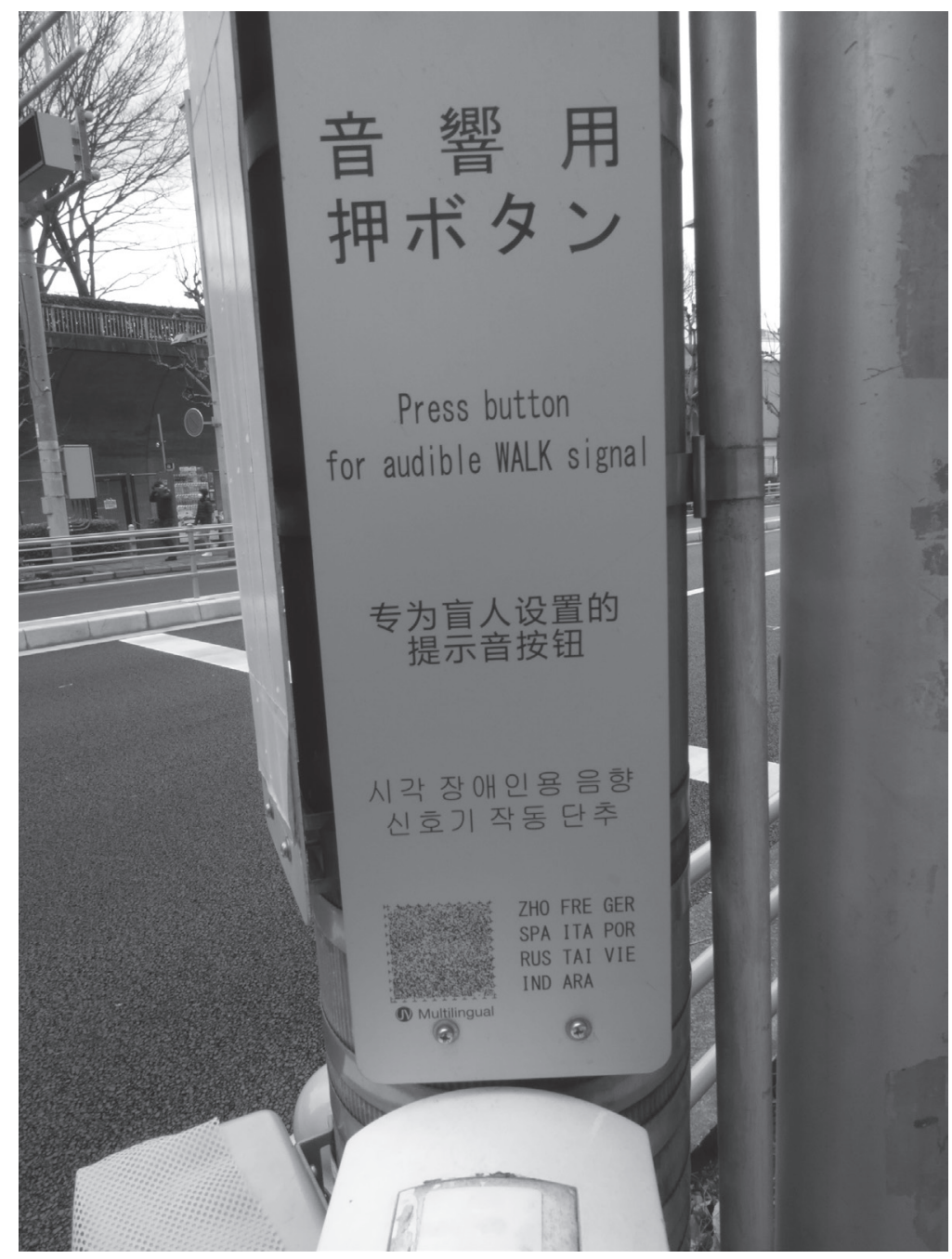

Figure 8.2 An audible traffic light signal next to the Olympic Stadium

assemblies' pictogram. These two examples demonstrate that pictograms do not completely work on arbitrary conventions (such as red signalling prohibition or danger), but use similarity (iconicity) to convey a message. No loud music, for example, happens to be difficult to convey in this way.

Planning for the Tokyo Olympics sets the ambitious aim to get rid of all sorts of barriers, but it simply: (1) delivers websites that facilitate the creation of high-quality multilingual information materials, and (2) reduces the official linguistic landscape from four to two languages as the default model. Foreign residents have never been considered, and neither have those who fall between the invented binary of 'monolithic Japanese versus the monolithic rest of world' such as various types of bilinguals, transnational migrants, individuals with one Japanese and one non-Japanese parent $(h \bar{a} f u$ ), or indigenous minorities. Let us consider next what this implies for urban translation. 


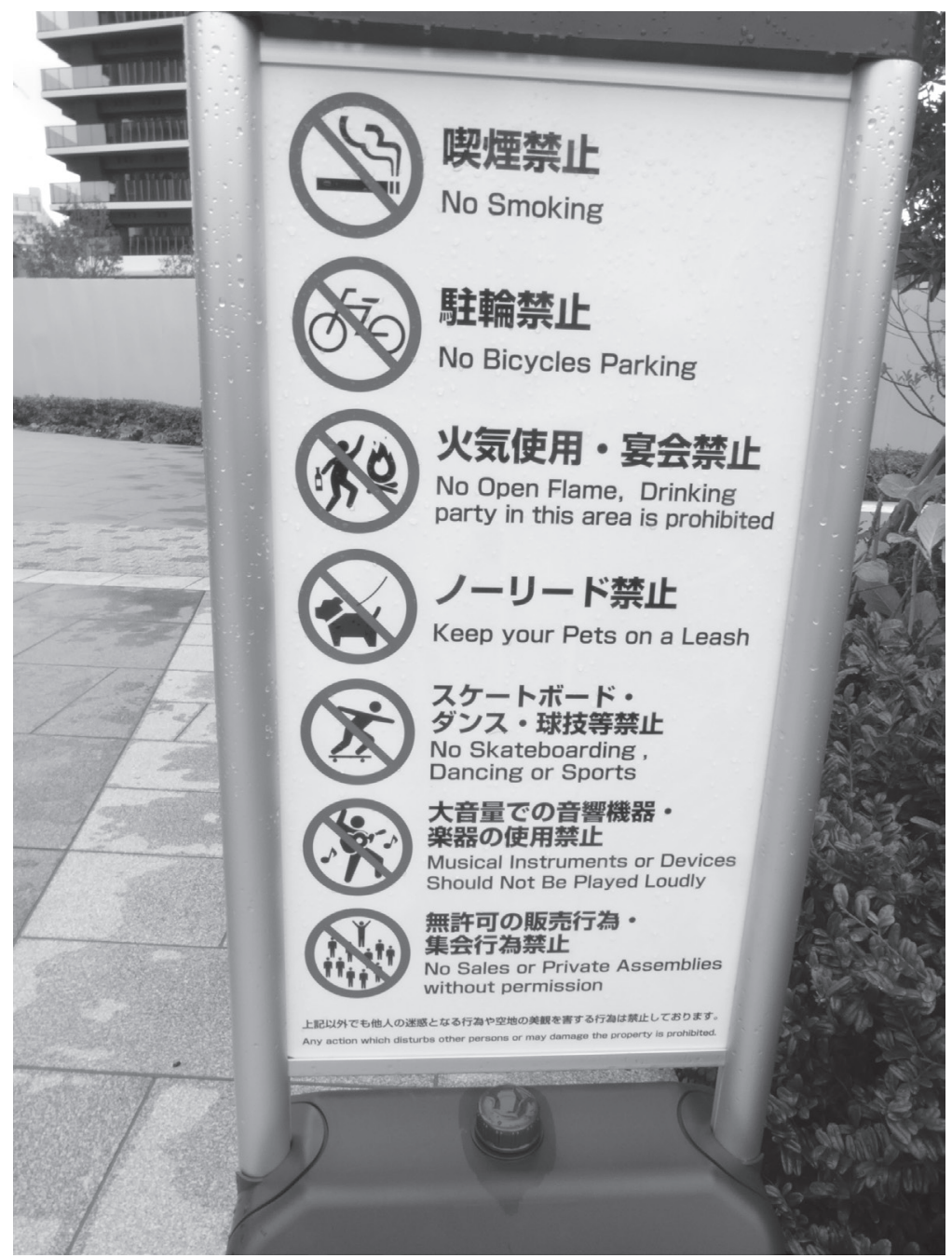

Figure 8.3 The prohibitions in front of the Japan Olympic Museum

\section{Perceived problems, alignment and conviviality in urban translation}

More often than not, languages in contact are languages in competition, a competition into which language policy and planning interferes (Tollefson 1991). Public space is invested with power, inequalities, challenges and struggles. This explains to some extent the contrast we find between the complex sociolinguistic situation in Tokyo and the simple binary JapaneseEnglish language regime in the public sphere. The implemented order is not functional in facilitating efficient communication with Tokyo's public. As a matter of fact, research into this issue was never consulted. Language planning and the resultant linguistic landscape is powerinfested. This is also why diversity among Tokyo residents was never considered. Tokyo's foreign residents are not powerful enough. 
Just like all other human activities, translation does not take place in a social vacuum. It is invested with power. This is important to recall because " $[\mathrm{t}]$ ranslation has come to us through the humanist tradition as a "friendly" word, a process implying god will and harmonious outcomes' (Simon 2016: 7). The presence or absence of a language in public space symbolically communicates the (un)importance of a given language (Heinrich 2011). The issue of power is thus evident in the fact that putting the dominant language of Japan (Japanese) aside, the second language to be prominently used in the official linguistic landscape is the most powerful language in the history of humankind, English. The newly imposed omission of Chinese and Korean is yet another act of the exercise of power. The linguistic landscape has not been adapted to the demographic composition of Tokyo. Rather, its two largest and oldest foreign communities have been purposefully excluded.

Tokyo can be heard and read. It can also be translated in the sense that efforts can be made to mitigate conflicts arising from its population density, diversity and mobility. Translating the city cannot easily be planned, because meaning in the public space is never fixed or stable but subject to constant negotiation. Meaning does not arise simply from 'language' as such, as it does from the actions, contexts and the concrete physical places where it is used to accomplish everyday tasks (Pennycook and Otsuji 2015; Otsuji and Pennycook, this volume). Urban spaces are filled with social actions, and urban translation seeks to direct such actions. In the course of doing so, the languages and presence of some are acknowledged, whereas others are being ignored. Urban translation renders some people and their languages unmarked, visible and in place, whereas others are marked, invisible and out of place. Let us consider this next on the example of the language planning and the linguistic landscape implemented for the 2020 Tokyo Games.

In the following, our discussion puts into relation (a) what is conceived of as a problem in public space, (b) how the public is conceived to be aligned with the implemented solution of the perceived problem, and (c) what this implies for the conviviality of the diverse people populating Tokyo's public space. I regard the interrelation among these three phenomena to be a process of urban translation.

In its overtly stated objective, urban translation for the Tokyo Olympics seeks to remove barriers to realizing a multilingual society in order to promote mutual understanding and foster mutual respect. Somewhat less overtly, the differences between Tokyo and other former Olympic host cities are also seen as an issue that needs to be addressed, and there is also a lingering doubt of whether Tokyo is sufficiently international, cosmopolitan and global in the perception of others. This double objective of 'becoming barrier-free' and of 'projecting a cosmopolitan and global (English) image' are seen as the key issues to be solved. Tokyo's existing and growing diversity is actually not addressed in this process, nor is the fact that a multilingual society does not need to be 'realized', but that its existence needs to be 'acknowledged' (which is not the case here). One cannot but arrive at the conclusion that despite all the rhetoric about multilingualism and multiculturalism, Japan continues to see itself as a linguistically and culturally homogenous society, and that this monolithic self-perception prepares the ground for regarding the rest of the world as monolithic and English-speaking. The Self and the Other are essentialized and then confronted with one another, and this invented confrontation is then perceived to be best dealt with by 'understanding' and 'respecting' these imposed differences. Japan presents itself as monolingual and monolithic, both to the inside and to the outside.

The selection of perceived problems, and the problems ignored thereby, have consequences regarding how individuals in Tokyo's diverse public are aligned to the imagined linguistic order. There is a gap between the linguistic repertoires and the linguistic landscape, and this is inevitable in any act of urban translation. However, in the case of planning for the 2020 
Games, this gap has become wider through the reduction of languages used in the official linguistic landscape. In other words, new barriers have been erected in a space where multilingual support (tagengo taiō) turns out to be Japanese plus English. English serves thereby the twin roles as the international lingua franca and as a means to stage differences between (all) Japanese and (all) non-Japanese. If we think of these decisions as a translation process, then information has not been 'domesticating'. The linguistic landscape is 'foreignizing' Tokyo's many Chinese and Korean foreign residents and tourists. Rather than rendering the unknown familiar by maintaining these languages, the unknown remains foreign for many. Translation is relegated to those in public space who do not speak Japanese or English in a linguistic landscape that now refuses to accommodate its two largest linguistic minorities. In practical terms, this means that those who do not know Japanese have to rely solely on English. They are integrated into the public sphere as unspecific 'international', 'global' or 'cosmopolitan' visitors. This is one interpretation. The second is that the presence of Chinese and Korean residents and visitors takes a back seat to the numerically smaller groups of visitors from other countries. The linguistic landscape and the administered public space are not simply filled with language - they are filled with norms, expectations and attitudes towards the various people making up the public. Chinese and Korean are not as valued as they once were. These languages and their speakers are rendered out of place in Tokyo in the new linguistic landscape. The desire to project Tokyo as a cosmopolitan and global city via English takes precedence over the overtly declared ambition to remove linguistic barriers. The translation cares more about the impression on its reader than about the effects of being read and understood. A large part of the walkers of Tokyo's public are creating its urban text, but their contribution is hidden, downplayed or wiped out. They are not reading their presence in the urban text in the very literal sense of the word.

What then about the conditions under which non-Japanese speakers are part of Tokyo's newly regimented public sphere? Not providing foreign language information is one thing, withdrawing it quite another, and withdrawing it when claiming to reduce linguistic barriers yet again another thing. Tokyo's urban translation does not adapt to its readers, but the readers have to adapt to the text. Tokyo's revamped public space is more about representation than about communication. This insight goes hand in hand with the many efforts to improve the quality and to standardize the English on display in the public space (via information sites on the web). Multilingualism remains poorly understood. When we encounter it, as in the example of the 'multilingual traffic light', then this multilingualism is cosmetic or ludic in nature. It is not driven by necessity but by pleasure and aesthetic motives (it looks good). In creating a new linguistic landscape for the 2020 Games, a chance has been missed to accommodate Chinese and Korean residents and visitors, to acknowledge their presence in the city and make them feel in place, and to add them to the official text that creates the sense of Tokyoness.

'Unity in diversity' might have been taken too literally, in that one unitary language is presented for a diverse population in Japan and another for a diverse population outside of Japan. Unity in diversity does never actually acknowledge diversity. Departing from the refusal to take existing diversity into account, language planning and the implemented linguistic landscape engage in finding solutions of how to align the monolithic other into a monolithic Japanese society. Tokyo's legacy of the 2020 Games might very well be an exaggerated concern to present itself as multicultural and cosmopolitan while being unable to be so. Ambition bites the nails of success. The translation is failing its stated objective, and it is relegated to those who differ from stereotypical views about Japan and the rest of the world. Multilingualism and global communication have arrived in Tokyo, but they remain poorly understood by those who were put in charge of urban translation for the 2020 Games. 


\section{Further reading}

Backhaus, Peter (2007) Linguistic Landscape. A Comparative Study of Urban Multilingualism in Tokyo, Clevedon: Multilingual Matters.

A classic of Japanese sociolinguistics and an empirical study of the linguistic landscape of Tokyo's central Yamanote Loop Line, the very heart of the megalopolis

Heinrich, Patrick, Hidenori Masiko and Katsuo Nawa (eds.) (2019) Tōkyō. Kotoba to toshi no tōgōteki rikai e [Tokyo. Towards an Integrated Study of Language and the City], Tokyo: Sangensha.

Explores what we mean when we talk about Tokyo and Tokyo language and offers a critical approach to look back at past achievements and seek to develop innovative methodologies of how to study language in Tokyo

Smakman, Dick and Patrick Heinrich (eds.) (2018) Urban Sociolinguistics: The City as a Process and an Experience, Abingdon and New York: Routledge.

Explores urban sociolinguistics on the basis of cases from around the world, in which it critiques the north-south divide in the production of knowledge and invites theorizations on urban sociolinguistics from around the world

\section{Acknowledgements}

I am indebted to Federico Picerni for a critical reading and constructive feedback of the first draft of this chapter. All remaining errors and shortcomings are entirely mine.

\section{References}

Aniya, Masa'aki (1989) 'Kengai dekasegi to kennai ijū' [Work-migration outside the prefecture and migration within the prefecture], in Okinawa Kyōiku I'inkai (ed.) Okinawa kenshi [History of Okinawa Prefecture], vol. 87, Tokyo: Kokuso Kankō, 423-474.

Atkinson, David (2015) Shin-kankō rikkoku-ron [New Tourist State-Building], Tokyo: Tōkyō Keizai Shinpō.

Backhaus, Peter (2007) Linguistic Landscapes. A Comparative Study of Urban Multilingualism in Tokyo, Clevedon: Multilingual Matters.

BOPGTP [Bureau of Olympic and Paralympic Games Tokyo 2020 Preparation] (2014-2020) 'Tagengotaiō kyōgi-kai pōtarusaito' [Portal site of the council for multilingual support], www. 2020games.metro.tokyo.lg.jp/multilingual/index.html (accessed 27 March 2020).

BOPGTP [Bureau of Olympic and Paralympic Games Tokyo 2020 Preparation] (2016) 'Towards 2020. Building the legacy', file://C:/Users/patri/Desktop/Towards\%202020-Building\%20the $\% 20$ Legacy-.pdf (accessed 12 September 2019).

Collon, Michael (1986) 'Some elements of a sociology of translation: Domestication of the scallops and the fishermen of St Brieuc Bay', in John Law (ed.) Power, Action and Belief: A New Sociology of Knowledge? London: Routledge and Kegan Paul, 196-223.

Cultural Agency (2018) 'Hensei 27-nendo "kokugo ni kansuru seron chōsa" no kekka to gaiyō' [Results and summary of the 2015 public opinion survey on national language], www.bunka.go.jp/ tokei_hakusho_shuppan/tokeichosa/kokugo_yoronchosa/pdf/h27_chosa_kekka.pdf (accessed 1 November 2019).

de Certeau, Michel (1984) The Practice of Everyday Life, trans. Steven Rendall, Berkeley, CA: University of California Press.

Deprez, Christine (2018) 'The city as a result of experience. Paris and its nearby suburbs', in Dick Smakman and Patrick Heinrich (eds.) Urban Sociolinguistics: The City as a Process and an Experience, Abingdon and New York: Routledge, 148-161.

Eberhard, David M., Gary F. Simmons and Charles D. Fennig (eds.) (2019) Ethnologue: Languages of the World (22nd edition), Dallas, TX: SIL International.

Heinrich, Patrick (2011) 'Language choices at Naha Airport', Japanese Studies 30: 342-358. 
Heinrich, Patrick (2012) The Making of Monolingual Japan: Language Ideology and Japanese Modernity, Bristol: Multilingual Matters.

Heinrich, Patrick (2019) 'Tōkyō. Shakai gengogakuteki katei to shite no, shakai gengogakuteki keiken to shite' [Tokyo as a sociolinguistic experience and process], in Patrick Heinrich, Hidenori Masiko and Katsu Nawa (eds.) Tōkyō. Kotoba to toshi no tōgōteki rikai e [Tokyo. Towards an Integrated Study of Language and the City], Tokyo: Sangensha, 7-24.

Heinrich, Patrick and Christian Galan (eds.) (2011) Language Life in Japan: Transformations and Prospects, Abingdon and New York: Routledge.

Heinrich, Patrick and Rika Yamashita (2018) 'Tokyo. Standardization, ludic language use and nascent superdiversity', in Dick Smakman and Patrick Heinrich (eds.) Urban Sociolinguistics: The City as a Process and an Experience, Abingdon and New York: Routledge, 166-182.

Ichikawa, Hirō (ed.) (2015) Tōkyō 2025. Besto gorin no toshi senryaku [Tokyo 2025. Best Olympic City Strategy], Tokyo: Tōyō Keizai Shinbun-sha.

Imai, Heide (2018) Tokyo Roji: The Diversity and Versatility of Alleys in a City in Transition, Abingdon and New York: Routledge.

Inoue, Fumio (2015) 'Keizaigaku no kangaegata. Tōkyō orinpikku no gengo keikan’ [The philosophy of the economy of language. The Tokyo Olympics and linguistic landscape], Nihongogaku [Japanese Language Studies] 34(6): 2-13.

Itagaki, Ryuta (2015) 'The anatomy of Korea-phobia in Japan', Japanese Studies 35(1): 1-18.

Kitajima, Hideyuki (2015) 'Orinpikku pararinpikku taikaigo mo misue, tagengo taiō suishin de toshiryoku kyōka o' [In anticipation of the Tokyo Olympic and paralympic games, strengthening urban power by promoting multilingual support], Jihyō [Time Review], 146-152.

Liddicoat, Anthony J. (2013) Language-in-Education Policies. The Discursive Construction of Intercultural Relations, Bristol: Multilingual Matters.

Maher, John C. and Kyōko Yashiro (eds.) (1995) Multilingual Japan, Clevedon: Multilingual Matters.

Mansfield, Stephen (2016) Tokyo. A Biography, Tokyo: Tuttle.

Ministry of Justice (2018) 'Comprehensive measures for acceptance and coexistence of foreign nationals (Provisional Translation)', www.moj.go.jp/content/001301382.pdf (accessed 27 March 2020).

Ministry of Justice (2019) 'Zairyū gaikokujin tōkei' [Statistics on foreign residents], www.moj.go.jp/ housei/toukei/toukei_ichiran_touroku.html (accessed 1 November 2019).

Ministry of Land, Infrastructure, Transport and Tourism (2014) 'Kankō rikkoku jitsugen ni muketa tagengotaiō no kaizen kyōka no tame no gaidorain' [Guidelines for improving and strengthening multilingual support for the realization of a tourism nation], www.mlit.go.jp/common/001029742.pdf (accessed 28 March 2020).

Nakane, Ikuo, Emi Otsuji and William S. Armour (eds.) (2015) Languages and Identities in a Transitional Japan, New York and Abingdon: Routledge.

Nakashima, Takeshi (2016) ‘Rōji no nihongo riterashī jissen. Yomikaki no esunogurafi' [Japanese literacy practice of Deaf children. Ethnography of literacy], Shakai gengogaku [Sociolinguistics] 16: 1-35.

Oguma, Eiji (2002) A Genealogy of 'Japanese'Self-Images, Melbourne: Trans Pacific Press.

Otomo, Ruriko (2019) 'Language and migration in Japan', in Patrick Heinrich and Yumiko Ohara (eds.) Routledge Handbook of Japanese Sociolinguistics, Abingdon and New York: Routledge, 91-109.

Otsuji, Emi (2019) 'Metrolingualism in transitional Japan', in Patrick Heinrich and Yumiko Ohara (eds.) Routledge Handbook of Japanese Sociolinguistics, Abingdon and New York: Routledge, 143-157.

Ozawa, Takato (2019) 'Orinpikku to tagengo taiō' saikō. Nanno tame no tagengo taiō-ka?' [Rethinking the 'multilingual support' of the Olympics. What is the aim of multilingual support?], Kotoba to shakai [Language and Society] 21: 28-51.

Pennycook, Alastair and Emi Otsuji (2015) Metrolingualism: Language in the City, Abingdon and New York: Routledge.

Robson, Graham (2016) 'Multiculturalism and the 2020 Tokyo Olympics', Kankōgaku kenkyū [Tourism Studies] 15: 51-58.

Sassen, Saskia (1991) The Global City. New York, London, Tokyo, Princeton, NJ: Princeton University Press. 
Seargeant, Philip (2009) The Idea of English in Japan. Ideology and Evolution of a Global Language, Bristol: Multilingual Matters.

Shakai Jijō Dēta Zuroku (2019) 'Beichūkan no shokoku ni taishite shitashimi o kanjiru hito no wariai no sui' $i$ ' [Trends in the percentage of people who feel sympathy for the US, China and Korea], https:// honkawa2.sakura.ne.jp/7900.html (accessed 28 March 2020).

Simon, Sherry (2016) 'Introduction', in Sherry Simon (ed.) Speaking Memory: How Translation Shapes City Life, Montreal: McGill-Queen's University Press, 3-20.

TOCOPG [The Tokyo Organising Committee of the Olympics and Paralympic Games] (2012) 'Tōkyō 2020 orinpikku pararinpikku shōchi i'inkai ga surōgan oyobi posutā o happyō!' [Tokyo 2020 Olympic and Paralympic bid committee announces slogans and posters!], https://tokyo2020.org/jp/news/ bid/20120529-01.html (accessed 12 September 2019).

TOCOPG [The Tokyo Organising Committee of the Olympics and Paralympic Games] (2019) 'Games vison', https://tokyo2020.org/en/games/vision/ (accessed 31 October 2019).

Tokyo Bureau of Industrial and Labor Affairs (2017) 'Economic trends in Tokyo', www.sangyo-rodo. metro.tokyo.jp/toukei/2-overview-2017en.pdf (accessed 31 October 2019).

Tokyo Metropolitan Government (n.d.) 'Tagengo menyū sakusei shien uebusaito' [Website for support in creating multilingual restaurant menus], www.menu-tokyo.jp/menu/ (accessed 28 March 2020).

Tokyo Metropolitan Government (2016) Towards 2020: Building the Legacy, Tokyo: Tokyo Metropolitan Government.

Tokyo Metropolitan Government (2018) 'Population of Tokyo', www.metro.tokyo.jp/ENGLISH/ ABOUT/HISTORY/history03.htm (accessed 31 October 2019).

Tollefson, James (1991) Planning Language, Planning Inequality, New York: Longman.

TOPJK [Tōkyō-to orinpikku pararinpikku junbi-kyoku] (2016) '2020-nen orinpikku pararinpikku taikai ni muketa tagengo taiō' [Multilingual measures in preparation for the 2020 Olympic and Paralympic games], Nihongo kyōiku [Journal of Japanese Language Teaching] 165: 18-29.

Watson, Mark K. (2014) Japan's Ainu Minority in Tokyo, Abingdon and New York: Routledge.

White, James (2011) Mirrors of Memory. Culture, Politics, and Time in Paris and Tokyo, Charlottesville, VA: University of Virginia Press.

Yasuda, Toshiaki (2011) 'Tagengo shakai' to iu gensō [A Fantasy Called 'Multicultural Society'], Tokyo: Sangensha. 